\title{
sciendo
}

\section{Sustainable Entrepreneurship in the Romanian Sports Industry}

\author{
Mihaela-Cornelia DAN \\ The Bucharest University of Economic Studies, Bucharest, Romania \\ mihaela.dan@fabiz.ase.ro
}

PICBE $\mid 647$

\begin{abstract}
Sustainable entrepreneurship is a new business driven concept with the aim to increase both social and business value. The three pillars of sustainable entrepreneurship are people, profit and planet. The question that comes frequently in discussion is how businesses can mix these three and bring human beings in a balance with the nature by keeping the profit goal. Sports industry registered a huge increase in the last twenty years, including Romania, especially on the side of amateur sports people, usually employees who are seeing sports activity as a way of reaching the life-work balance and a way of destressing after a hard working day. Sports entrepreneurs observed very quickly the opportunity of this form of spending free time, especially through activities done outside in the nature and started to organize diverse events like mountain marathons, cross biking, duathlons etc. The novelty comes from the fact that many events, especially in Romania, have the component of "planet". People are participating because e.g. part of the fee is financing ecological or social projects in different regions of the country. The aim of this paper is to analyze the concept of sustainable entrepreneurship in relation with different sports events and answer to some questions. How many organizers take into account the social part of the events? Are they more interested in ecological, social or other type of value? Participants decide where to go based on the social or ecological causes financed? Based on different research methods the author is outlining the typology of sports events at the amateur level in Romania and the interest of combining the profit with the social value goal. The results of the study might be of interest for several groups of stakeholders (public authorities, NGOs, companies, managers etc.) when developing public policies, proposing life-work balance programs and other measures aimed at stimulating sustainable entrepreneurship.
\end{abstract}

Keywords: sustainable entrepreneurship, sports industry, Romania, business value, social value

\section{Literature review}

Sustainable entrepreneurship is the mainstream (Sarango-Lalalui et.al, 2018) that combines sustainable management decisions with entrepreneurial thinking and acting. It relies on people and profit goals with the scope of nature protection and economic-social equilibrium.

The focus on sustainable development at the academic level is seen in the high number of articles and papers that analyze the characteristics, challenges and future development of it. On a brief bibliometric analysis within Clarivate Analytics database I found the topic of sustainable entrepreneurship researched between 1995 - 2019 in 1255 articles, 631 proceeding papers, 123 book chapters and 106 other document types.

Because the topic is too general I decided to research only articles that include in the title the keyword sustainable entrepreneurship. This shortens the list and results in 174 articles, 73 proceedings papers, 34 book chapters and 30 other document types (book reviews, editorial materials etc.).

The interest for sustainable entrepreneurship as research field registers a constant increase since 2010 with a major momentum in 2018, an increase of $23.68 \%$. Referring to the areas of research and knowledge in which authors published researches on sustainable 
entrepreneurship, the majority regards business economics (182 documents), environmental sciences ecology (53 documents), science technology other topics (45 documents), social sciences other topics (25 documents). Further documents focus on research areas as engineering, public administration, education or agriculture.

Sustainable entrepreneurship is an international research field, authors belong to major European, North American or Australian universities (e.g. University Liverpool, Colorado State University, Copenhagen Business School or Auckland University of Technology).

Given the diversity of research areas, origin of authors and different analysis approaches it is worth to define the concept of sustainable entrepreneurship.

The association of entrepreneurship and sustainability concepts may be unrealistic, entrepreneurship's main goals are growth - business, money, jobs, competition, technological change and productivity. How can a company be in the same time sustainable? The Cambridge Dictionary defines sustainability as "the quality of causing little or no damage to the environment and therefore able to continue for a long time" (dictionary.cambridge.org, 2019). And sustainable is defined by the same source as " causing little or no damage to the environment and therefore able to continue for a long time". So, any company that fulfils its goals with the given resources and satisfies the market needs and does not compromise the chances and resources of the future generations is sustainable.

Various descriptions from diverse sources show some common elements when defining sustainable entrepreneurship (Table 1).

Table 1 Definitions of sustainable entrepreneurship

\begin{tabular}{|l|l|}
\hline \multicolumn{1}{|c|}{ Authors } & \multicolumn{1}{|c|}{ Definition } \\
\hline $\begin{array}{l}\text { Pacheco, D.F.; Dean, T.J.; } \\
\text { Payne, D.S. }\end{array}$ & $\begin{array}{l}\text { We view sustainable entrepreneurship as the discovery, creation, evaluation, } \\
\text { and exploitation of opportunities to create future goods and services that is } \\
\text { consistent with sustainable development goals. }\end{array}$ \\
\hline Young,W.; Tilley, F. & $\begin{array}{l}\text { An innovative, market-oriented and personality driven form of creating } \\
\text { economic and societal value by means of break-through environmentally or } \\
\text { socially beneficial market or institutional innovations. }\end{array}$ \\
\hline Dorfman, R. & $\begin{array}{l}\text { The examination of how opportunities to bring into existence future goods } \\
\text { and services are discovered, created, and exploited, by whom, and with what } \\
\text { economic, psychological, social, and environmental consequences. }\end{array}$ \\
\hline Dean, T.J.; McMullen, J.S. & $\begin{array}{l}\text { The process of discovering, evaluating, and exploiting economic opportunities } \\
\text { those are present in market failures which detract from sustainability, } \\
\text { including those that are environmentally relevant. }\end{array}$ \\
\hline Thananusak, T. & $\begin{array}{l}\text { Sustainable entrepreneurship is the process of discovering, creating, } \\
\text { exploiting opportunities to achieve triple bottom line' or creating benefits for } \\
\text { society, the planet, and profit. }\end{array}$ \\
\hline
\end{tabular}

Source: Author's own design,

Based on these definitions, sustainable entrepreneurship creates or discovers opportunities, especially environmentally driven, while taking into account also the social needs of the community. Necessary elements for a successful project as innovation, skilled people, and value creation have the same relevance in sustainable entrepreneurship as in the "general" entrepreneurship.

Sarango-Lalangui et.al. (2018) state that the background of sustainable entrepreneurship has the roots in the environmental and social role of the enterprise in the 
society. The value creation of a company brings into discussion not only the economic and social impact but also the direct and indirect influences on the environment.

Elkington (1997) who claims to have introduced the concept of triple bottom line in 1994, shows that adopting the accounting framework with social, environmental and financial gives a deeper and better image of the company's performance and assists decision makers in finding new opportunities for organizational development and value creation.

Kraus et. al. (2018) stresses that it is important to translate sustainability into a tangible product through preservation, transformation and adding novelty.

Felnhofer (2017) claims that sustainable entrepreneurs bring new symbols, construct new measures, build consensus in the community and facilitate new relations between institutions.

Starting from Schumpeter's point of view (1934) that entrepreneurs have to recombine different resources and deliver a creative destruction, than sustainable entrepreneurship gives the tools to succeed.

Beginning with the 1990s the research focus expanded in order to discover the possible link between entrepreneurial processes and environmental and social problems. New concepts occur - ecopreneurship or green entrepreneurship - with focus on nature, environment, social entrepreneurship - which creates social wealth and societal value and sustainable entrepreneurship which takes into account all three sides - economic, social and environmental with the benefit for people, planet and companies (e.g. profit) (Thanannusak, 2019). The so-called "triple bottom line" brings "a new perspective on the correlations between economic prosperity, social justice and environmental protection and posited the importance of long-term objectives" (Soto-Acosta et.al., 2016).

The link between sustainable entrepreneurship and social entrepreneurship is systematically researched, Bansal, Garg and Sharma (2019) conclude in their newest research that entrepreneurs' knowledge, innovative abilities and innovative power play an important role in recognizing the opportunities of sustainable entrepreneurship; they define entrepreneurs as "engines of sustainable development" or "vehicles for meeting unmet social needs".

\section{Entrepreneurship in sports}

Sport as an industry is one of the largest global industries with a focus on social innovation and entrepreneurship and a high influence on education and tourism (Ratten, 2011). Sport is an important source of well-being and economic activity. According to the recent Study on the economic impact of sport through sport satellite accounts in the European Union (European Union, 2018) sport accounts for $2.12 \%$ of the GDP and sport-related employment accounts 5,67 million people, almost 3\% of the EU employment. The study reveals that when the economy is suffering, sport is a very resilient sector, it generates growth and jobs. Sport is a complex industry and it does not limit to the sport activity, it is related to education services, sport services, accommodation and food services, retail, human health services or transportation services.

Entrepreneurship in sports is a new challenge of researchers and practitioners, Ratten (2010) states that entrepreneurship and sport management literature have seldom crossed paths in the academic research. 
Briefly, entrepreneurship in sports refers to sports-related organization (sports club, sports association, sport company) that is acting and innovating in a business context. Management and marketing in sport is special because it cannot be put in practice without fans emotions, emotional or symbolic attachment to athletes, clubs, sport brands, sport products etc. (Chalip, 2004). In general, sport is based on collaboration and community orientation between different stakeholders, such as athletes, customers, fans, sponsors, communities, government and employees (Ratten, 2010) and it has an entrepreneurial nature because it is permanently adapting to suit changing societal needs (Ratten, Babiak, 2010).

Recently, sport organizations focused also on sustainability initiatives because sport interacts also with the environment, by including manufacturers, local authorities, event organizers and consumers.

Sport is linked also to social entrepreneurship because the sport community can innovate in order to create social and financial benefit for the community as whole (Ratten, 2010). Sports teams can partner with local authorities for sports projects (e.g. building sports arenas or stadiums), or with NGOs for protecting nature or helping disadvantaged people or social groups. So, sports based organizations do not have an implicit need for making profit, the financial objective is important in achieving sports-related goals.

In comparison with venture capitalists, sports entrepreneurs show some interesting characteristics: they have the tendency to finance their business through personal funds or outside resources (family, friends), they seek independency or other financial and social rewards and having a background in a particular sport gives them a competitive advantage in identifying and exploiting a sports-related business venture (Ratten, 2011).

\section{Sport events development in Romania}

According to the above mentioned study of the European Union (2018), the driving sector of sport-related economic activity in Romania is education services, accounting for $26 \%$ of the employment in the industry. Also important are sport services, the production of textiles and apparel. Overall, the Romanian sport industry generates 100.000 jobs and produces 1,388.8 m Euros of GDP.

Even in this conditions, there is a lack of scientific information regarding the development of sport after 1989, and especially about the existence of sport entrepreneurship. Fact is that there are sport entrepreneurs that identified market opportunities and needs coming from the economic development of Romania, and based on the changing behavior of people, especially employees in international companies located here. Starting with 2000s we observe that people are more interested in well-being and a healthy life, more sports and fitness clubs develop in the country, companies encourage their employees to practice a sport or even finance personal development projects such as "Primul meu maraton" (My first marathon by Raiffeisen Bank). Becoming a Member State brought the opportunity for introducing and developing new sports fields such as triathlon, mountain running or biking. The sports development on amateur side registered a boom which is easy to observe by the high number of fitness and sports clubs or the number of participants in big events like Bucharest Marathon. Within this movement, first sports entrepreneurs start their business in different sport fields and with diverse goals. In general, they act as individuals or associations with the scope of promoting sport in nature, protecting the environment, providing sports educational services and a healthy life. 
A specific characteristic of this development is introducing a social or environmental cause as part of the sport event. Sports entrepreneurs in Romania tend to replace the authorities and solve punctual problems, such as helping disadvantaged social groups or people, protect nature or sponsoring children in school. How does it work? The participant pays a fee for the sport event and part of it finances a special cause (e.g. Hospice Casa Sperantei at the Bucharest Marathon) or he can choose for what cause to spend the money. There are events where this type of support is transformed into individual fundraising and the athlete has the personal project to persuade people to sponsor the social or environmental causes (e.g. Transmaraton). One best practice example is the platform galantom.ro, another type of sports entrepreneurship, which started with sports projects and now expanded to more diverse like nature, health, animal protection or community development. Since it started in 2012 the platform facilitated the fundraising of 9.7 million RON (approx. 2 million EUR), in 549 events, which gathered 229 organizations and 7000 individuals, with an average donation of 133,00 RON (approx. 28,00 EUR). The long-time impact of this type of sports entrepreneurship was not measured yet, but if we look at some well-known events where the number of participants increases every year we may state that it was not an inhibitive factor (e.g. Semimaraton Iasi, Baneasa Forest Run, Bucharest Halfmarathon etc.). Another option on the platform allows participants to fundraise permanently for the chosen cause, so in a way these people develop their own project similar to entrepreneurs.

According to the platform sportsplanner.ro in 2018447 sports events for amateurs were organized in Romania. The majority were running events (including marathons, half marathons, cross) around 320 events, followed by mountain bike events (82 events), duathlons and triathlons and other type of sports. From these sport events, around 35\% include as a conceptual element a social or environmental cause, a situation, a problem and/or needs to be solved that attracts the participants, for instance financial and material help for poor people, afforestation around urban centers, a better access to touristic areas by introducing or replacement of road signs, help for people with incurable diseases etc.

\section{Best practice examples in the Romanian sports entrepreneurship}

On a short analysis of the main amateur sports events in Romania I choose some best practice examples that are worth to be presented here.

Transmaraton is a mountain running event that takes place on the well-known Transfagarasan route with an elevation of $2000 \mathrm{~m}$ (transmaraton.org). From the beginning the event was introduced as a "running and fundraising platform" and since the first edition in 2011 it collected over 1 million RON (approx. 210.000 EUR) for partner causes and created a real impact. Usually, participants may choose one of three causes, for instance for the 2019 edition the causes are Forest School - a project to reconnect people and especially children with nature, Hospice Casa Sperantei - a project for cancer patients and Young Talents - a program for art skilled children from poor communities. An interesting aspect is that each participant has its own support and fundraising page, so each person is becoming an entrepreneur by promoting not only the event, but also the supported cause and fundraises money. The concept relies also on the multiplication factor where registered participants attract future athletes or donators. Another element of the event is the exclusivity, only 200 participants are accepted every year, which makes more attractive the event and the demand. 
Another example is Crosul Padurii (crosulpadurii.ro) which started 10 years ago and had the goal of afforestation in the southern part of the country and now the preservation of the 64 hectares of planted trees. The initiator is a NGOs which discovered very quickly the impact of sport in the environmental projects. Having a controversial situation in Romania with a massive deforestation, the orientation toward protecting the woods attracted very quickly participants to a running event that takes place every year in Bucharest. Interesting fact is that participants are also invited to join the NGO team when planting trees. In this way the organizer builds a relationship with participants who will join also the next editions.

Cozia Mountain Run is another mountain running event that implicates the participants in more social causes. It started in 2012 and included from the beginning a social cause in the event concept. In general, the organizers donate part of the fees for poor families, centers for abandoned children or help disabled people to travel through the woods with special vehicles. Interesting fact is that the organizers choose the situations to solve from the region where the event takes place, so it delivers also a regional support. The transparency in the funds spending gives confidence and guarantees the good intentions.

The collaboration of sports entrepreneurs with different associations and NGOs seems to be a win-win situation. There is a range of associations who are sustaining social and environmental causes but do not have the necessary resources or funds to organize and develop this type of sports events. In this case, the sport entrepreneur takes the responsibility of the social cause and the association delivers volunteers for the event. In general, sport events integrate deeply volunteers for supporting activities and also a successful survive on the market. Good examples in Romania are the Bucharest Marathon and Bucharest Half Marathon. The organizers created a special platform "Voluntar in sport" (Volunteer in sports) that brings together voluntary offerings. Started as an exclusive platform for these two events, it developed into a community for people with civic spirit (voluntarinsport.ro) that delivers volunteers for different events in Romania.

Although profit is not the first goal of sustainable entrepreneurship, sport entrepreneurship as part of it can attract funds for developing events and give also the necessary tools to solve social and environmental problems. The collaboration between companies and event organizers contributes to a brand image increase, sustains corporate social responsibility projects and transfers a positive image to the sport entrepreneurs. For instance a well-known event is Maratonul Vinului - a mountain bike event that is sponsored by Procter\&Gamble Romania and part of the fees are donated to a program for preventing school drop-out in the region where the company has production facilities.

\section{Conclusion}

The present research paper focuses on the development of a trending concept of sustainable entrepreneurship and its implications for the society, companies, public etc. Based on a bibliometric analysis of the Clarivate Analytics database I found an increased interest in this subject, mainly after 2010 when politicians, communities, organizations, companies delivered several statements and research projects showing that we need to be more carefully with the environment and people, and take consistent decisions in this way.

The literature review revealed that sustainable entrepreneurship has similarities with all types of entrepreneurship, and includes on top the environment aspect. Companies are more carefully with their influence on nature or on the region where they produce, 
communities become closer and take more responsibility in solving their problems with own means. The triple bottom line concept (Elkington, 1997) is still a valuable instrument for company's analysis.

Sustainability concept has major influences in every industry today and sport is one good example. Sport builds relationships between athletes, links communities, brings together companies, authorities and people, it brings excellent opportunities for delivering tools and solutions to different societal problems.

The sport industry in Romania registered an important increase after 1989, and especially the amateur sport events developed exponentially due to the behavior changes of citizens. Work-life balance, a healthier longer life and the prevention of illnesses switched the attention of people to possibilities and occasions to put in practice the new behavior.

Because Romania is still in a developing period and the state is often unable to react to the diverse problems, sport entrepreneurship and, especially, sport events are the base for implementing solutions and developing projects for environment and society. I present some good practice examples, that might be unique also outside Romania and worth to be deeper analyzed.

The paper is an exploratory research because of the limited access to data regarding the Romanian market, but also European. 2006 European Union recognized the importance of the sport industry for the economy and launched few research reports about the performance of this sector. Still, only ten Member States report constant on the sport industry and its implications.

Future research on the subject of sustainable entrepreneurship may focus on the regional influence and impact of such market initiatives, on the increased responsibility of citizens regarding the environment where they leave and the inheritance to future generations.

\section{References}

Bansal, S., Garg, I., Sharma, G.D., (2019). Social Entrepreneurship as a Path for Social Change and Driver of Sustainable Development: A Systematic Review and Research Agenda, Sustainability, 11, 1-28.

Dorfman, R. (1993). Some concepts from welfare economics. In Economics of the Environment: Selected Readings; WW Norton: New York, NY, USA, cited in SarangoLalangui, P., Santos J.L.S., Hormiga, E. (2018), The Development of Sustainable Entrepreneurship Research Field, Sustainability, 10, 1-19.

Dean, T.J.; McMullen, J.S. (2007). Toward a theory of sustainable entrepreneurship: Reducing environmental degradation through entrepreneurial action. Journal of Business Venture, 22, 50-76.

Elkington, J. (1997). Cannibals with Forks: The Triple Bottom Line of 21st Century Business; Capstone: Oxford, UK.

European Union (2018). Study on the economic impact of sport through sport satellite accounts, https://publications.europa.eu/en/publication-detail/-/publication/865ef44c-5ca111e8-ab41-01aa75ed71a1/language-en/format-PDF/source-71256399

Fellnhofer, K. (2017). Drivers of innovation success in sustainable businesses. Journal of Cleaner Production, 167, 1534-1545.

Kraus, S.; Burtscher, J.; Vallaster, C.; Angerer, M. (2018). Sustainable Entrepreneurship 
Orientation: A Reflection on Status-Quo Research on Factors Facilitating Responsible Managerial Practices. Sustainability, 10, 444.

Pacheco, D.F.; Dean, T.J.; Payne, D.S. (2010). Escaping the green prison: Entrepreneurship and the creation of opportunities for sustainable development. Journal of Business Venture, $25,464-480$.

Ratten, V. (2010). Developing a theory of sport-based entrepreneurship, Journal of

PICBE $\mid 654$ Management \& Organization, 16 (4), 557-565.

Ratten, V. (2011). Social entrepreneurship and innovation in sports, International Journal of Social Entrepreneurship and Innovation, 1(1), 42-54.

Ratten, V., Babiak, K. (2010). The role of social responsibility, philanthropy and entrepreneurship in the sport industry, Journal of Management \& Organization, 16 (4), 482-487.

Ratten, V. (2015). Athletes as entrepreneurs: the role of social capital and leadership ability, International Journal of Entrepreneurship and Small Business, 25(4), 442-455.

Sarango-Lalangui, P., Santos J.L.S., Hormiga, E. (2018). The Development of Sustainable Entrepreneurship Research Field, Sustainability, 10, 1-19.

Schumpeter, J.A. (1934). The Theory of Economic Development; Harvard University Press: Cambridge, MA, USA.

Soto-Acosta, P., Cismaru, D.M., Vatamanescu, E.M., Ciochina, R.S. (2016). Sustainable Entrepreneurship in SMEs: A Business Performance Perspective, Sustainability, 8, 112.

Thananusak, T. (2019). Science Mapping of the Knowledge Base on Sustainable Entrepreneurship, 1996-2019, Sustainability, 11, 1-20.

Young, W.; Tilley, F. (2006). Can businesses move beyond efficiency? The shift toward effectiveness and equity in the corporate sustainability debate. Business Strategy Environment, 15, 402-415.

Crosulpadurii.ro, accessed March 2019

Coziamountainrun.ro, accessed March 2019

Galantom.ro, accessed March 2019

Maratonulvinului.ro, accessed March 2019

Sportsplanner.ro, accessed March 2019

Transmaraton.org, accessed March 2019

Voluntarinsport.ro, accessed March 2019 